\title{
Comparison of attenuated and virulent West Nile virus strains in human monocyte-derived dendritic cells as a model of initial human infection
}

\author{
Daniel J Rawle ${ }^{\dagger}$, Yin Xiang Setoh ${ }^{\dagger}$, Judith H Edmonds and Alexander A Khromykh*
}

\begin{abstract}
Background: The human-pathogenic North American West Nile virus strain (WNV $\left.{ }_{N Y g 9}\right)$, responsible for the outbreak in New York city in 1999, has caused 41000 infections and 1739 human deaths to date. A new strain of West Nile virus emerged in New South Wales, Australia in 2011 (WNV Nsw2011), causing a major encephalitic outbreak in horses with close to 1000 cases and 10-15\% mortality. Unexpectedly, no human cases have so far been documented.

Findings: We report here, using human monocyte-derived dendritic cells (MoDCs) as a model of initial WNV infection,

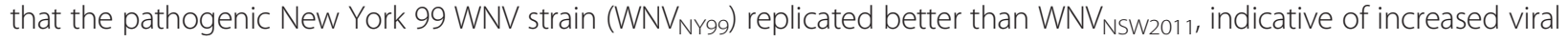
dissemination and pathogenesis in a natural infection. This was attributed to suppressed viral replication and type I interferon (IFN) response in the early phase of $W_{N V_{N Y 9 g}}$ infection, leading to enhanced viral replication at the later phase of infection. In addition, $W_{N V_{N Y 9 g}}$ induced significantly more pro-inflammatory cytokines in MoDCs compared to WNV $V_{\text {NSW2011. }}$
\end{abstract}

Conclusions: Our results suggest that the observed differences in replication and induction of IFN response between $W_{N V_{N Y 99}}$ and $W_{N V_{N S W 2011}}$ in MoDCs may be indicative of their difference in virulence for humans.

Keywords: West Nile virus, Dendritic cells, Monocyte, Pathogenesis, Virulence

\section{Findings}

West Nile virus (WNV) is the leading cause of arboviral encephalitis in the Americas with over 41000 infections and 1739 human deaths (http://www.cdc.gov/westnile/ index.html, accessed 25/11/2014) since the outbreak of a human virulent strain in New York in $1999\left(\mathrm{WNV}_{\mathrm{NY} 99}\right.$ strain) $[1,2]$. There is currently no effective treatment or approved WNV vaccine for use in humans. A strain of WNV called Kunjin ( $\left.\mathrm{WNV}_{\mathrm{KUN}}\right)$ has been circulating in Australia since it was discovered in 1960, and have caused very few symptomatic infections in humans or horses [3]. This was until a new strain of WNV emerged in New South Wales in $2011\left(\mathrm{WNV}_{\mathrm{NSW} 2011}\right)$ causing a major encephalitic outbreak in over 1000 horses [4,5]. $\mathrm{WNV}_{\mathrm{NSW} 2011}$ has likely emerged through mutations of previously circulating $\mathrm{WNV}_{\mathrm{KUN}}$, and gained at least two

\footnotetext{
* Correspondence: alexander.khromykh@uq.edu.au

${ }^{\dagger}$ Equal contributors

Australian Infectious Diseases Research Centre, School of Chemistry and Molecular Biosciences, The University of Queensland, St Lucia, Queensland 4072, QLD, Australia
}

(c) 2015 Rawle et al.; licensee BioMed Central. This is an Open Access article distributed under the terms of the Creative Commons Attribution License (http://creativecommons.org/licenses/by/4.0), which permits unrestricted use, distribution, and reproduction in any medium, provided the original work is properly credited. The Creative Commons Public Domain Dedication waiver (http://creativecommons.org/publicdomain/zero/1.0/) applies to the data made available in this article unless otherwise stated. known virulence determinants found in the humanpathogenic $\mathrm{WNV}_{\mathrm{NY} 99}$ strain [4]; i) the N-linked glycosylation on the E protein associated with increased virulence in mice [6], and ii) the phenylalanine residue at position 653 of NS5 which is a potent inhibitor of STAT1 phosphorylation [7].

The horses affected by the $\mathrm{WNV}_{\mathrm{NSW} 2011}$ outbreak presented with similar clinical symptoms to horses infected with $\mathrm{WNV}_{\mathrm{NY} 99}$, therefore it was rather unexpected that the $\mathrm{WNV}_{\text {NSW2011 }}$ outbreak had no reported human cases. This prompted us to investigate the viral growth kinetics and immune induction profiles of $\mathrm{WNV}_{\mathrm{NSW} 2011}$ compared to $\mathrm{WNV}_{\mathrm{NY} 99}$ using cultures of primary human dendritic cells (DCs) as a model of initial infection in humans [8-11]. Human MoDCs were used as an ex vivo model of initial WNV infection in this study, because it has been shown that large numbers of bone marrow monocytes differentiate into DCs soon after WNV infection in the dermis [12]. Human MoDCs have been previously used to show that WNV replication was required for type I IFN induction, and this was a result 

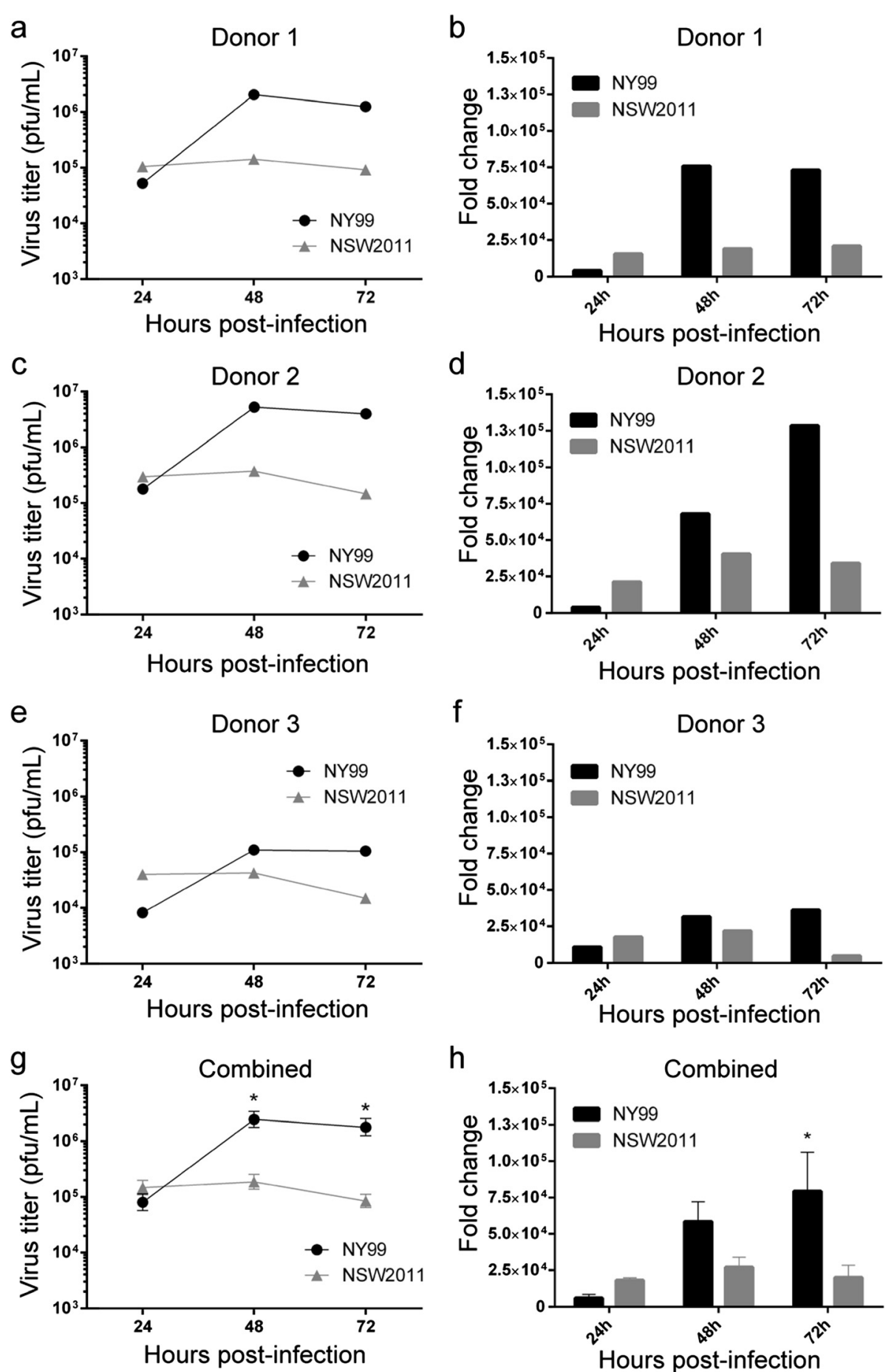

Figure 1 Replication of $\mathbf{W N V}_{\mathbf{N Y} 99}$ and $\mathbf{W N V}_{\text {NSW2011 }}$ in human MoDCs. MoDCs from donors 1 (a, b), 2 (c, d) and 3 (e, f) were infected with $W V_{N Y 99}$ and $W_{N V_{N S W 2011}}$ at $M O I=1$. Cell culture supernatant was collected at 24,48 and 72 hours post-infection and virus titer was determined by plaque assay on BHK cells (a, $\mathbf{c}$, e). Total cellular RNA was collected at 24, 48 and 72 hpi and vRNA levels as determined by qRT-PCR were normalised to a combination of three endogenous controls (TBP, GAPDH and PPIA), and was expressed as fold change from uninfected samples $(\mathbf{b}, \mathbf{d}, \mathbf{f})$. The data from all donors (donors 1 to 3) were combined and error bars represent standard error of the mean (g, h). A Student's t-test was performed to determine statistical significance at each time point $(*: \mathrm{P} \leq 0.05)$. 

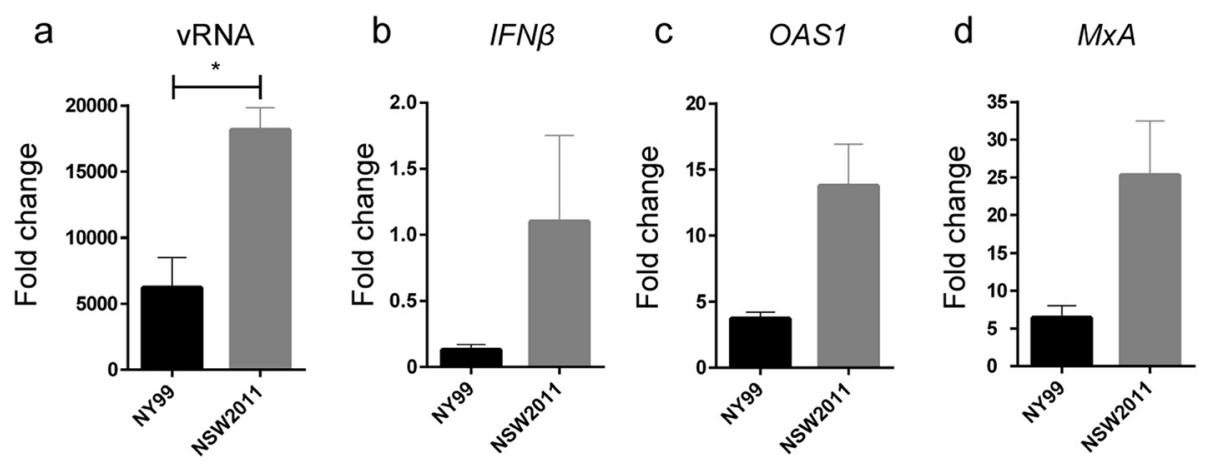

Figure 2 Early IFN/ISG response to infection with $\mathbf{W N V}_{\mathrm{NY} 99}$ and $\mathbf{W N V}_{\mathrm{NSW2011}}$ in human MoDCs. MoDCs from three separate donors were infected with $W_{N V_{N Y 99}}$ or $W N V_{N S W 2011}$ at MOI $=1$ and total cellular RNA was isolated at 24 hours post-infection. VRNA (a), IFNB (b), OAS1 (c) and MXA (d) mRNA levels as determined by qRT-PCR were normalised to a combination of three endogenous controls (TBP, GAPDH and PPIA), and expressed as fold change from uninfected samples. The results show mean values from three different donors (donors 1 to 3 ) and error bars represent standard error of the mean. A Student's t-test was performed to determine statistical significance (*: $\mathrm{P} \leq 0.05$ ).

of IRF3 translocation to the nucleus after dsRNA stimulation of RIG-1, MDA5 or TLR3 [13]. While comparison of WNV strains has been previously performed in DCs to show that WNV strains with glycosylated envelope (E) protein have increased infection and replication rates [14], $\mathrm{WNV}_{\mathrm{NY} 99}$ and $\mathrm{WNV}_{\mathrm{NSW} 2011}$ both have glycosylated $\mathrm{E}$ [4], and are therefore expected to be equally efficient in viral entry into MoDCs through attachment to DC-SIGN or DC-SIGNR receptors [11]. Therefore, additional differences must exist that result in either productive infection of DCs or effective viral clearance by the innate immune response.

To investigate this, we used MoDCs by isolating peripheral blood mononuclear cells (PBMCs) from human buffy coat from three donors, which were tested to be negative for arboviral infections, then performed CD14+ magnetic selection to isolate monocytes. The isolated monocytes were cultured with GM-CSF and IL-4 for 6 days to differentiate into immature MoDCs, which were then matured upon WNV infection represented by increased CD80 and CD86 expression. Briefly, at 48 hours post infection (hpi), 78.7\% of $\mathrm{WNV}_{\mathrm{NY} 99}$-infected MoDCs and $84.5 \%$ of $\mathrm{WNV}_{\mathrm{NSW} 2011}$-infected MoDCs showed CD80 upregulation, and $93.9 \%$ of $\mathrm{WNV}_{\mathrm{NY} 99}$-infected MoDCs, $95.8 \%$ of $\mathrm{WNV}_{\mathrm{NSW} 2011}$-infected MoDCs showed CD86 upregulation.

To compare the ability of $\mathrm{WNV}_{\mathrm{NY} 99}$ and $\mathrm{WNV}_{\mathrm{NSW} 2011}$ to productively infect these initial target cells, MoDCs were infected with $\mathrm{WNV}_{\mathrm{NY} 99}$ and $\mathrm{WNV}_{\mathrm{NSW} 2011}$ (passage 1 stocks grown in Vero76 cells) at a multiplicity of infection (MOI) of 1 and cell culture supernatant and total cellular RNA was harvested at 24, 48 and $72 \mathrm{hpi}$. Our results revealed that $\mathrm{WNV}_{\mathrm{NY} 99}$ produced similar titers to $\mathrm{WNV}_{\mathrm{NSW} 2011}$ at 24 hpi for donor 1 (Figure 1a) and donor 2 (Figure 1c), but less virus compared to $\mathrm{WNV}_{\mathrm{NSW} 2011}$ for donor 3 (Figure 1e). At later times of infection (48 and 72 hpi), $W_{N V_{N Y 99}}$ consistently produced higher titers than $\mathrm{WNV}_{\mathrm{NSW} 2011}$ (Figure 1a, c, and e). A similar trend was observed by qRT-PCR analysis of intracellular vRNA levels, showing reduced RNA replication for $\mathrm{WNV}_{\mathrm{NY} 99}$
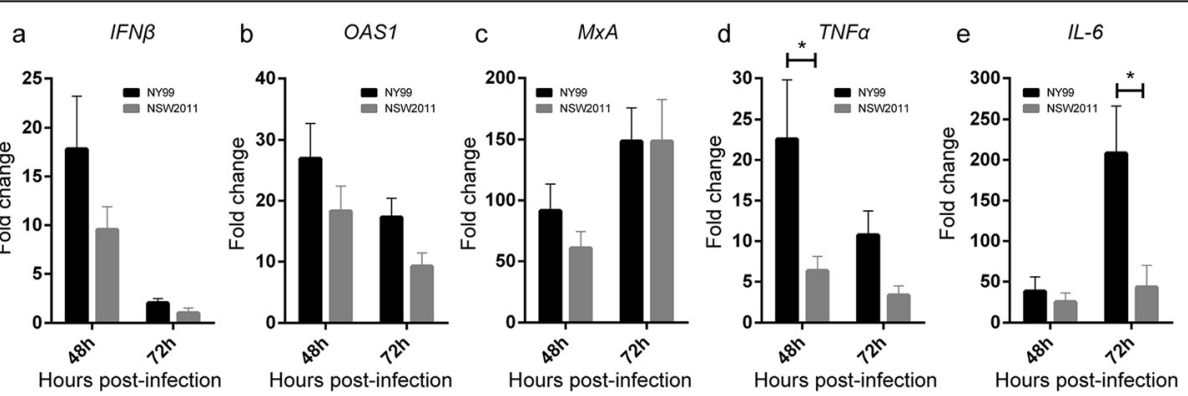

Figure 3 Late IFN/ISG and pro-inflammatory cytokine response to infection with WNV $_{\text {NYg9 }}$ and WNV $_{\text {NSW2011 }}$ in human MoDCs. MoDCs from three separate donors were infected with $W_{N V_{N Y 99}}$ or $W_{N V_{N S W 2011}}$ at $\mathrm{MOI}=1$ and total cellular RNA was isolated at 48 and 72 hours postinfection. IFNB (a), OAST (b), MXA (c), TNFa (d) and IL-6 (e) mRNA levels as determined by qRT-PCR were normalised to a combination of three endogenous controls (TBP, GAPDH and PPIA), and expressed as fold change from uninfected samples. The results show mean values from three different donors (donors 1 to 3 ) and error bars represent standard error of the mean. A Student's t-test was performed to determine statistical significance at each time point (*: $P \leq 0.05)$. 
compared to $\mathrm{WNV}_{\mathrm{NSW} 2011}$ at $24 \mathrm{hpi}$, but increased RNA replication for $\mathrm{WNV}_{\mathrm{NY} 99}$ compared to $\mathrm{WNV}_{\mathrm{NSW} 2011}$ at 48 and 72 hpi (Figure 1b, d, and f). It was also interesting to note that for all three donors, $\mathrm{WNV}_{\mathrm{NSW} 2011}$ viral titers and vRNA failed to increase after 24 hpi (Figure 1a-f), indicating that $\mathrm{WNV}_{\mathrm{NSW} 2011}$ could not productively replicate in MoDCs while $\mathrm{WNV}_{\mathrm{NY} 99}$ could. In addition, we observed significant variability between human donors, as cells isolated from donor 3 (Figure 1e and $\mathrm{f}$ ) were more resistant to WNV infection than donors 1 and 2 (Figure 1a-d), which may reflect the high variability in disease symptoms observed in natural human WNV infections $[9,15]$. When the data from all three donors were combined, $\mathrm{WNV}_{\mathrm{NY} 99}$ produced significantly more virus particles at 48 and 72 hpi $(\mathrm{p}<0.05$, Figure $1 \mathrm{~g})$, and replicated to significantly higher vRNA levels at $72 \mathrm{hpi}(\mathrm{p}<0.05$, Figure $1 \mathrm{~h})$. This confirms the hypothesis that $\mathrm{WNV}_{\mathrm{NY} 99}$ was able to replicate more efficiently than $\mathrm{WNV}_{\mathrm{NSW} 2011}$ in MoDCs, which could possibly translate into increased dissemination in the body, and increased virulence. The enhanced replication of $\mathrm{WNV}_{\mathrm{NY} 99}$ compared to $\mathrm{WNV}_{\mathrm{NSW} 2011}$ was similarly shown in previous studies conducted in our laboratory using commonly used immortalised cell lines $[4,16]$.

It was hypothesized that differences in replication were associated with host innate immune response generated against the viruses. Therefore, qRT-PCR analysis of $I F N \beta, O A S 1, M x A, T N F \alpha, I L-6$ and viral RNA (vRNA) expression was performed in the context of $\mathrm{WNV}_{\mathrm{NY} 99}$ and $\mathrm{WNV}_{\mathrm{NSW} 2011}$ infections. Interestingly, at the early phase of infection (24 hpi), MoDCs infected with $\mathrm{WNV}_{\mathrm{NY} 99}$ had reduced levels of vRNA $(\mathrm{p}<0.05$, Figure $2 \mathrm{a})$, IFN $\beta$ mRNA (Figure 2b), OAS1 mRNA (Figure 2c) and $M x A$ mRNA (Figure 2d) compared to MoDCs infected with $\mathrm{WNV}_{\mathrm{NSW} 2011}$. In contrast, at the later phase of infection (48 and $72 \mathrm{hpi}$ ), RNA levels for $\mathrm{WNV}_{\mathrm{NY} 99}$ were increased (Figure $1 \mathrm{~h}$ ), which likely explains the increased induction of IFN $\beta$ (Figure 3a), OAS1 (Figure 3b) and MxA mRNAs (Figure 3c), as well as a significant increase in induction of proinflammatory cytokines TNFa (48 hpi p < 0.05 , Figure $3 \mathrm{~d}$ ) and $I L-6$ (72 hpi $\mathrm{p}<0.05$, Figure $3 \mathrm{e})$.

The upregulation of $T N F \alpha$ and $I L-6$ is likely to occur via viral dsRNA activation of TLR3 $[9,17,18]$. Studies in vivo have shown that TLR3 knockout mice were more resistant against WNV encephalitis, and this was linked to decreased TNF $\alpha$ and IL-6 expression [18]. The proposed mechanism of this is that TNF $\alpha$ and IL- 6 secreted into the bloodstream from infected leukocytes may induce endocytosis and degradation of tight junction proteins (Claudin-1, JAM-1 and occludin) of the blood brain barrier (BBB), causing breakdown of the BBB and allowing WNV entry into the brain [18-22].

Our finding that $\mathrm{WNV}_{\mathrm{NY} 99}$, but not $\mathrm{WNV}_{\mathrm{NSW} 2011}$, suppresses early viral RNA replication in MoDCs is supported by previous reports. Scherbik et al. [23] showed that the pathogenic lineage 1 strain of WNV (Eg101), but not the non-pathogenic lineage 2 strain (W956IC), suppressed early viral RNA replication (but increased viral protein expression), resulting in reduced host innate immune responses at the early phase of infection. This effect of early IFN suppression was also shown for pathogenic vs. non-pathogenic Tick Borne Encephalitis virus (TBEV) strains [24]. These two studies suggest that pathogenic viral strains more effectively suppress early viral RNA replication but increase translation, which has three outcomes that favour virulence; i) decreasing the amount of viral dsRNA to decrease IFN induction, ii) increased viral non-structural protein production to block the JAK/STAT signalling cascade, and iii) more effective viral protein-dependent remodelling of cellular membranes which house replication complexes [23,25].

Taken together, our results have identified that a possible factor leading to higher human virulence of $\mathrm{WNV}_{\mathrm{NY} 99}$ is likely to be decreased viral RNA replication and lower induction of IFN $\beta, O A S 1$ and $M x A$ early in MoDCs infection. This likely facilitates the enhanced replication of $\mathrm{WNV}_{\mathrm{NY} 99} \mathrm{vRNA}$ and dissemination of particles later in infection.

\section{Competing interests}

The authors declare that they have no competing interest.

\section{Authors' contributions}

DR: generation of data, data analysis and interpretation, preparation of MS; YXS: conception and design, data analysis and interpretation, preparation of MS; JE: conception and design, interpretation of data; AK: conception and design, interpretation of data, preparation and revision of MS. All authors read and approved the final manuscript.

\section{Acknowledgements}

We acknowledge the help of the Australian Red Cross Blood Service for providing buffy coat, and Jesse Fyrk (Australian Red Cross Blood Service Research Assistant) for organising and distributing the buffy coat on request. This work was supported by the National Health and Medical Research Council of Australia (APP1045188).

Received: 22 January 2015 Accepted: 12 March 2015

Published online: 22 March 2015

\section{References}

1. Roehrig JT. West nile virus in the United States - a historical perspective. Viruses. 2013;5:3088-108.

2. Brinton MA. The molecular biology of West Nile Virus: a new invader of the western hemisphere. Ann Rev Microbiol. 2002;56:371-402.

3. Hall RA, Broom AK, Smith DW, Mackenzie JS. The ecology and epidemiology of Kunjin virus. Curr Top Microbiol Immunol. 2002;267:253-69.

4. Frost MJ, Hick P, Read A, Hobson-Peters J, May FJ, Doggett SL, et al. Characterization of virulent West Nile virus Kunjin strain, Australia, 2011. Emerg Infect Dis. 2012;18:792-800.

5. Roche SE, Wicks R, Garner MG, East IJ, Paskin R, Moloney BJ, et al. Descriptive overview of the 2011 epidemic of arboviral disease in horses in Australia. Aust Vet J. 2013;91:5-13.

6. Beasley DW, Whiteman MC, Zhang S, Huang CY, Schneider BS, Smith DR, et al. Envelope protein glycosylation status influences mouse neuroinvasion phenotype of genetic lineage 1 West Nile virus strains. J Virol. 2005;79:8339-47. 7. Laurent-Rolle M, Holbrook MR, Barrett AD, Mason PW, Bloom ME, GarcíaSastre A, et al. The NS5 protein of the virulent West Nile virus NY99 strain is a potent antagonist of type I interferon-mediated JAK-STAT signaling. J Virol. 2010;84:3503-15 
8. Johnston L, Halliday GM, King NJ. Langerhans Cells Migrate to Local Lymph Nodes Following Cutaneous Infection with an Arbovirus. J Investigative Dermatology. 2000;114:560-8

9. Suthar MS, Diamond MS, Gale JM. West Nile virus infection and immunity. Nat Rev Microbiol. 2013;11:115.

10. Elizabeth JS, Drew W, Nicholas C, Benhur L, Lesley SM, George L, et al. Constitutive and induced expression of DC-SIGN on dendritic cell and macrophage subpopulations in situ and in vitro. J Leukoc Biol. 2002;71:445-57.

11. Davis CW, Nguyen HY, Hanna SL, Sanchez MD, Doms RW, Pierson TC. West Nile virus discriminates between DC-SIGN and DC-SIGNR for cellular attachment and infection. J Virol. 2006;80:1290-301.

12. Davison AM, King NJ. Accelerated Dendritic Cell Differentiation from Migrating Ly6Clo Bone Marrow Monocytes in Early Dermal West Nile Virus Infection. J Immunol. 2011;186:2382-96.

13. Silva MC, Guerrero-Plata A, Gilfoy FD, Garofalo RP, Mason PW. Differential activation of human monocyte-derived and plasmacytoid dendritic cells by West Nile virus generated in different host cells. J Virol. 2007:81:13640-8.

14. Martina BEE, Koraka P, van den Doel P, Rimmelzwaan GF, Haagmans BL, Osterhaus ADME. DC-SIGN enhances infection of cells with glycosylated West Nile virus in vitro and virus replication in human dendritic cells induces production of IFN-alpha and TNF-alpha. Virus Res. 2008;135:64

15. Samuel MA, Diamond MS. Pathogenesis of West Nile Virus infection: a balance between virulence, innate and adaptive immunity, and viral evasion. J Virol. 2006;80:9349-60.

16. Setoh YX, Prow NA, Rawle DJ, Tan CSE, Edmonds JH, Hall RA, Khromykh AA: Systematic analysis of viral genes responsible for differential virulence between American and Australian West Nile virus strains Journal of general virology 2015, Epub Jan 2015. doi:10.1099/vir.0.000069. [Epub ahead of print]). http://www.ncbi.nlm.nih.gov/pubmed/25626681.

17. Boehme KW, Compton T. Innate sensing of viruses by toll-like receptors. J Virol. 2004;78:7867-73.

18. Wang T, Town T, Alexopoulou L, Anderson JF, Fikrig E, Flavell RA. Toll-like receptor 3 mediates West Nile virus entry into the brain causing lethal encephalitis. Nat Med. 2004;10:1366-73.

19. Arjona A, Foellmer HG, Town T, Leng L, McDonald C, Wang T, et al. Abrogation of macrophage migration inhibitory factor decreases West Nile virus lethality by limiting viral neuroinvasion. J Clin Invest. 2007;117:3059-66.

20. Diamond MS. West Nile encephalitis virus infection: viral pathogenesis and the host immune response. New York: Springer; 2009.

21. Xu Z, Waeckerlin R, Urbanowski MD, van Marle G, Hobman TC. West Nile virus infection causes endocytosis of a specific subset of tight junction membrane proteins. PLoS One. 2012;7:e37886.

22. Marchiando AM, Shen L, Graham WW, Weber CR, Schwarz BT, Austin JR, et al. Caveolin-1-dependent occludin endocytosis is required for TNF-induced tight junction regulation in vivo. J Exp Med. 2010;207:111-26.

23. Scherbik SV, Pulit-Penaloza JA, Basu M, Courtney SC, Brinton MA. Increased early RNA replication by chimeric West Nile virus W956IC leads to IPS-1mediated activation of NF-KB and insufficient virus-mediated counteraction of the resulting canonical type I interferon signaling. J Virol. 2013;87:7952-65.

24. Overby AK, Popov VL, Niedrig M, Weber F. Tick-borne encephalitis virus delays interferon induction and hides its double-stranded RNA in intracellular membrane vesicles. J Virol. 2010;84:8470-83.

25. Courtney S, Scherbik S, Stockman B, Brinton M. West Nile virus infections suppress early viral RNA synthesis and avoid inducing the cell stress granule response. J Virol. 2012;86:3647-57.

\section{Submit your next manuscript to BioMed Central and take full advantage of:}

- Convenient online submission

- Thorough peer review

- No space constraints or color figure charges

- Immediate publication on acceptance

- Inclusion in PubMed, CAS, Scopus and Google Scholar

- Research which is freely available for redistribution 